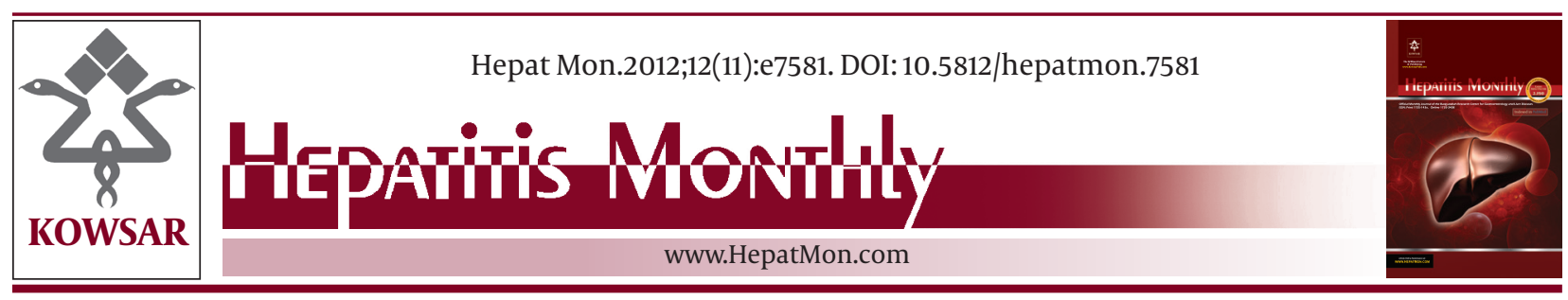

\title{
High Serum Levels of TGF- $\beta$ in Iranians With Chronic HBV Infection
}

\author{
Hossein Khorramdelazad ${ }^{1}$, Gholamhossein Hassanshahi ${ }^{1}$, Behzad Nasiri Ahmadabadi ${ }^{2}$, \\ Mohammad Kazemi Arababadi ${ }^{2}$ \\ ${ }^{1}$ Molecular Medicine Research Center, Rafsanjan University of Medical Sciences, Rafsanjan, IR Iran \\ ${ }^{2}$ Immunology of Infectious Diseases Research Center, Rafsanjan University of Medical Sciences, Rafsanjan, IR Iran
}

\begin{tabular}{l}
\hline A R T I C L E I N F O \\
\hline Article type: \\
Brief Report \\
\hline Article history: \\
Received: 03 Aug 2012 \\
Revised: 03 Sep 2012 \\
Accepted:17 Sep 2012 \\
\hline Keywords: \\
Hepatitis B, Chronic \\
Transforming Growth Factor Beta
\end{tabular}

\begin{abstract}
A B S T R A C T
Background: The transforming growth factor- $\beta$ (TGF- $\beta$ ) is an important cytokine with anti-inflammatory properties.

objectives: The main purpose of this study was to compare the serum levels of TGF- $\beta$ in a group of chronic HBV infected (CHB) patients as well as healthy individuals from South-East of Iran.

Patients and Methods: Sixty patients with $\mathrm{CHB}$ as well as sixty healthy individuals were enrolled in the study. ELISA technique was applied to measure the serum levels of TGF- $\beta$ in both groups.

Results: Our results revealed that the serum levels of TGF- $\beta$ were significantly increased in CHB patients in compare to healthy controls.

Conclusions: According to this result, it may be concluded that high serum levels of TGF- $\beta$ may be a mechanism by which immune response against HBV is suppressed.
\end{abstract}

Published by Kowsar Corp, 2012. cc 3.0.

Implication for health policy/practice/research/medical education:

This article is research study on chronic HBV infected patients to evaluate TGF- $\beta$ serum levels. This article can be useful for hepatologists, gastroentestinalists, Immunologists and virologists.

- Please cite this paper as:

Khorramdelazad H, Hassanshahi G, Nasiri Ahmadabadi B, Arababadi MK. High Serum Levels of TGF- $\beta$ in Iranians With Chronic HBV Infection. Hepat Mon. 2012;12(11)e:7581. DOI:10.5812/hepatmon.7581

\section{Background}

Iran is defined as a low endemicity part of the world for hepatitis B virus (HBV) infection, while, chronic form of the disease is frequent among HBV infected patients (1). Patients with chronic hepatitis B infection (CHB) are suffering from persistent HBV infection and the virus is not fully cleared from the hepatocytes (2). Several scientists proposed that the host genetic as well as epigenetic differences between patients and those who successfully clear the virus could be responsible for the prolongation of HBV infection $(3,4)$. Cytokines are small glycoproteins that are produced by immune cells and are involved in both inflammatory and anti-inflammatory reaction dur- ing diseases and heath (5). The TGF- $\beta$ is a famous member of anti-inflammatory cytokine family that is produced during hemostasis and tissue remodeling (6). Therefore, it is plausible to hypothesize that its up or downregulation may lead to inappropriate immune responses against viral hepatitis. Because, $\mathrm{CHB}$ patients are unable to completely eradicate HBV from their hepatocytes (1), a probable mechanism has been proposed in which chronic up-regulation of TGF- $\beta$ cause's decreased degree of immune responses to the infected hepatocytes (7).

\section{Objectives}

Therefore, we aimed to determine the serum levels of

\footnotetext{
${ }^{*}$ Corresponding author: Mohammad Kazemi Arababadi, Immunology of Infectious Diseases Research Center, Rafsanjan University of Medical Sciences, Rafsanjan, IR Iran. Tel:+98-3915234003-5, Fax:+98-3915225209, E-mail: dr.kazemi@rums.ac.ir

DOI:10.5812/hepatmon.7581

Copyright@ 2012 Kowsar Corp. All rights reserved.

This is an Open Access article distributed under the terms of the Creative Commons Attribution License (http://creativecommons.org/licenses/by/3.0), which permits unrestricted use, distribution, and reproduction in any medium, provided the original work is properly cited.
} 
TGF- $\beta$ in the Iranian patients with CHB compared with healthy individuals.

\section{Patients and Methods}

\subsection{Subjects}

Peripheral blood samples were collected from 60 patients with $\mathrm{CHB}$ among with 60 healthy controls from Rafsanjan (South-Eastern of Iran) in $5.5 \mathrm{~mL}$ tubes free of anti-coagulant. Patients with detectable HIV antibody and HCV-HBV co-infected patients were excluded from the study. The patients were selected as CHB using the "Guide of Prevention and Treatment in Viral Hepatitis" criteria (8). Controls were selected with matched age and sex (Table 1). The samples were centrifuged at $3500 \mathrm{rpm}$ for $4 \mathrm{~min}$ and serums were isolated immediately after collection. The serum samples were stored at $-20{ }^{\circ} \mathrm{C}$ for further cytokine analysis. This study was approved by the local ethical committee of the Rafsanjan University of Medical Sciences and informed written consent was obtained from all of participants, prior to sample collection.

\subsection{Detection of serological HBV markers and TGF- $\beta$}

ELISA technique was used for samples HBsAg, HBeAg (Behring, Germany) and TGF- $\beta$ (eBiosciences, Esp) screening using a commercial kit according to the manufacturer's guidelines. Data were only used when the inter and intra-assays produced the scores of $\mathrm{CV}<14 \%$ and $\mathrm{CV}$ $<3 \%$, respectively. HBV-DNA Extraction and Real-time PCR condition: Viral DNA was purified from $200 \mu \mathrm{L}$ of plasma from HBsAg positive patients using a commercial kit (Cinnaclon, Iran) according to the manufacturer's guidelines. HBV-DNA quantification was also done using a commercial kit from Primer Design Company (UK) following the manufacturer's instructions. Data analysis and statistical methods: The parametric statistical analyses were performed using the t-test under SPSS software version 18 and the Pvalue of less than 0.05 considered as significant.

Table 1. Laboratory and Demographic Information of CHB Patients and Healthy Controls

\begin{tabular}{|lll}
\hline & CHB Patients & Healthy Controls \\
\hline Age, $\mathbf{y}$, Mean \pm SD & $35 \pm 9$ & $38.41 \pm 7$ \\
\hline Liver function tests(LFT) & & \\
\hline ALT, Mean \pm SD & $27 \pm 12$ & $28 \pm 9$ \\
\hline AST, Mean \pm SD & $28 \pm 11$ & $29 \pm 5$ \\
\hline ALP, Mean \pm SD & $270 \pm 40$ & $240 \pm 20$ \\
\hline Sex & & \\
\hline Male, No. (\%) & $28(46.6 \%)$ & $31(48.3 \%)$ \\
\hline Female, No. (\%) & $32(53.4 \%)$ & $29(51.7 \%)$ \\
\hline
\end{tabular}

Abbreviations: ALT, Alanine aminotransferase; AST, Aspartate aminotransferase; ALP, Alkaline phosphatase; $\mathrm{CHB}$, Chronic HBV Infection.

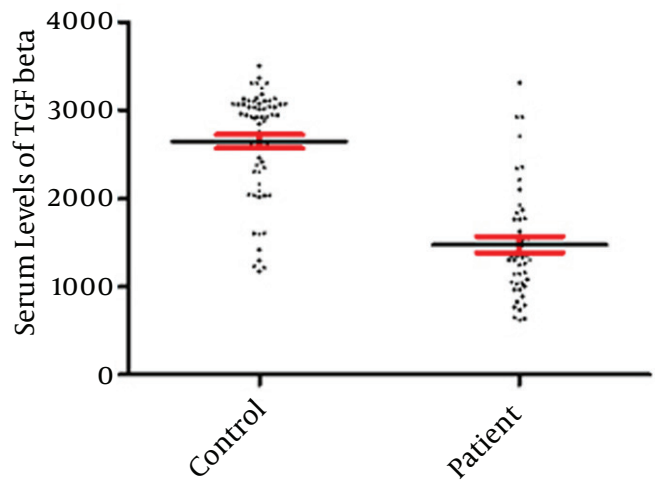

Figure 1. Demonstrates the Circulating Levels of TGF- $\beta$ in the CHB Patients and Healthy Controls

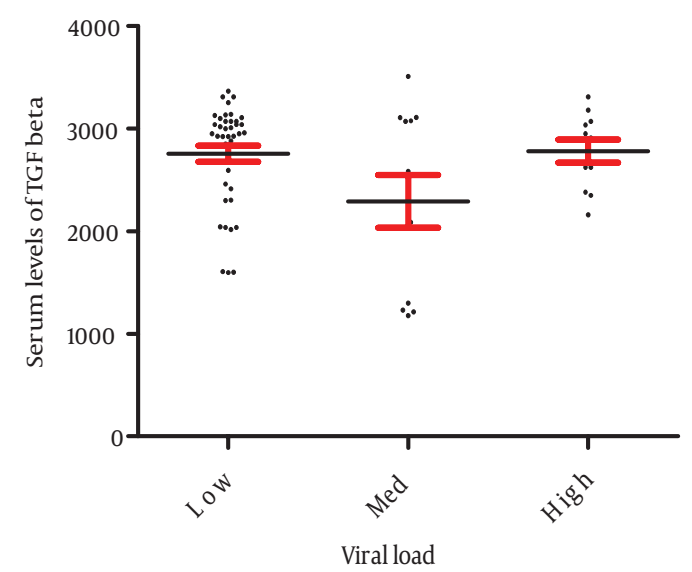

Figure 2. Demonstrates the Circulating Levels of TGF- $\beta$ in the CHB Patients With Different HBV Viral Load

\section{Discussion}

Our results revealed that all patients with $\mathrm{CHB}$ were positive for HBsAg with detectable HBV-DNA. Five (8.3\%) CHB patients were HBeAg positive with high HBV-DNA copy numbers (more than 1000000 Copy/ml). The results also demonstrated that 37 patients had fewer than 20000, 12 between 20000-400000 and 11 upper than 1000000 copy numbers/mL. All patients and healthy controls had normal serum levels of AST, ALT, and ALP (Table 1). Results of this study showed that serum levels of TGF- $\beta$ was significantly $(P<0.001)$ increased in CHB patients $(2648.5 \pm 77.35)$ in comparison with healthy controls $(1476.56 \pm 91.26)$ (Figure 1). The serum levels of TGF- $\beta$ were not different from CHB patients with different HBV copy numbers (Figure 2). The cytokines network plays important role during immune response against intracellular infections including viral infection (9). TGF- $\beta$, as an antiinflammatory cytokine, plays key roles in the regulation and suppression of immune responses (6). Therefore, any 
significant alteration in the expression of TGF- $\beta$ may lead to inappropriate immune responses against viral infections. Our results demonstrated that the expression of TGF- $\beta$ was increased in the CHB patients in comparing to healthy controls. Although, immune responses is complex and evaluation of a cytokine cannot be considered as whole feature of this system but based on our results it may be concluded that elevated expressions of TGF- $\beta$ may be in parallel with immune responses suppression, hence, the disease can be maintained in the CHB patients. Additionally, TGF- $\beta$ can induce apoptosis in hepatocytes (10); hence, the mechanisms which induce cirrhosis may be related to high levels of this cytokine in $\mathrm{CHB}$ patients. Interestingly, a previous study reported that TGF- $\beta$ downregulated the NKG2D/DAP10 and 2B4/SAP expression in human NK cells (7), thus this could be plausible proposed mechanism via it. TGF- $\beta$ may suppress immune responses in $\mathrm{CHB}$ patients. In agreement with present findings, Divella et al. indicated that serum levels of TGF- $\beta$ were higher in patients suffering from liver diseases (10). Another study that was undertaken on the Egyptian population also indicated that serum levels of TGF- $\beta$ were increased in the hepatocellular carcinoma patients (11). Interestingly, Gue et al. reported that the level of TGF- $\beta$ was significantly increased in the serum and liver tissues of the HBV infected patients with the progressive of fibrosis (12). Enhanced serum levels of TGF- $\beta$ in CHB patients also were reported by Lebensztejn et al., (13) and Akpolat et al., (14). Moreover, the polymorphisms within the TGF- $\beta$ gene were also showed to be associated with CHB (15). Additionally, the immune response process during HBV infection is complicated (16) and is highly related with the stage of hepatitis, hence, evaluation of several aspects of immune responses of $\mathrm{CHB}$ patients in different clinical presentation of HBV infection can be helpful to find out the main mechanisms involving the suppression of immune system during $\mathrm{HBV}$ infections. On the other hand, previous studies demonstrated that the immune response process is related to hepatocyte function $(17,18)$. Our results revealed that the serum levels of AST, ALT and ALP were not different between CHB patients and controls, hence, it seems that the hepatocyte function was unable to alter immune responses of the CHB patients and higher serum levels of TGF- $\beta$ is related to the other mechanisms. On the other hand, our results showed that the serum levels of TGF- $\beta$ were not different from CHB patients with different HBV copy numbers. Therefore, by the other means, our results may at least confirm that the production of TGF- $\beta$ was not affected by virus replication. In contrast to our results, Li et al. revealed that HBcAg induces TGF- $\beta$ production in CHB patients (19). Therefore, studies with larger sample size of CHB patients with $\mathrm{CHB}$ including inactive carriers as well as patients with more advance degree of liver disease are required to unravel the underlying mechanisms of probable association of TGF- $\beta$ expression with HBV replication.

\section{Acknowledgments}

Authors would like to appreciate all patients with $\mathrm{CHB}$ and healthy controls enrolled in this study.

\section{Authors' Contribution}

All of authors were involved in all steps of the manuscript preparation.

\section{Financial Disclosure}

None declared.

\section{Funding/Support}

This project was supported by a grant from Rafsanjan University of Medical Sciences.

\section{References}

1. Assar S, Arababadi MK, Mohit M, Ahmadabadi BN, Pumpens P, Khorramdelazad $\mathrm{H}$, et al. $\mathrm{T}$ helper and $\mathrm{B}$ cell escape mutations within the HBc gene in patients with asymptomatic HBV infection: a study from the South-Eastern region of Iran. Clin Lab. 2012;58(1-2):53-60.

2. Ahn SH, Kim do Y, Chang HY, Hong SP, Shin JS, Kim YS, et al. Association of genetic variations in CCR5 and its ligand, RANTES with clearance of hepatitis B virus in Korea. J Med Virol. 2006;78(12):1564-71.

3. Ahmadabadi BN, Hassanshahi G, Arababadi MK, Leanza C, Kennedy D. The IL-10 promoter polymorphism at position -592 is correlated with susceptibility to occult HBV infection. Inflammation. 2012;35(3):818-21.

4. Zhou J, Huang Y, Tian D, Xu D, Chen M, Wu H. Expression of tolllike receptor 9 in peripheral blood mononuclear cells from patients with different hepatitis B and C viral loads.J Huazhong Univ Sci Technolog Med Sci. 2009;29(3):313-7.

5. Arababadi MK, Pourfathollah AA, Jafarzadeh A, Hassanshahi G. Serum Levels of IL-10 and IL-17A in Occult HBV-Infected South-East Iranian Patients. Hepat Mon. 2010;10(1):31-5.

6. Regateiro FS, Howie D, Cobbold SP, Waldmann H. TGF-beta in transplantation tolerance. Curr Opin Immunol. 2011;23(5):660-9.

7. Sun C, Fu B, Gao Y, Liao X, Sun R, Tian Z, et al. TGF-beta1 downregulation of NKG2D/DAP10 and 2B4/SAP expression on human NK cells contributes to HBV persistence. PLoS Pathog. 2012;8(3):e1002594.

8. Liu HG, Chen WW, Fan ZP, Yang HY, Shi M, Zhang Z, et al. The high prevalence of the 27 mutant HBcAg18-27 epitope in Chinese HBVinfected patients and its cross-reactivity with the V27 prototype epitope. Clin Immunol.2007;125(3):337-45.

9. Arababadi MK, Nasiri Ahmadabadi B, Kennedy D. Current information on the immunologic status of occult hepatitis B infection. Transfusion. 2012;52(8):1819-26.

10. Divella R, Daniele A, Gadaleta C, Tufaro A, Venneri MT, Paradiso A, et al. Circulating transforming growth factor-beta and epidermal growth factor receptor as related to virus infection in liver carcinogenesis. Anticancer Res. 2012;32(1):141-5.

11. El-Tayeh SF, Hussein TD, El-Houseini ME, Amer MA, El-Sherbini M, Elshemey WM. Serological biomarkers of hepatocellular carcinoma in Egyptian patients. Dis Markers. 2012;32(4):255-63.

12. Guo JC, Bao JF, Chen QW, Li XO, Shi JP, Lou GQ, et al. [Level of serum and liver tissue TGF-beta1 in patients with liver fibrosis due to chronic hepatitis B]. Zhonghua Shi Yan He Lin Chuang Bing Du Xue Za Zhi. 2008;22(5):354-7.

13. Lebensztejn DM, Sobaniec-Lotowska M, Kaczmarski M, Werpachowska I, Sienkiewicz J. Serum concentration of transforming growth factor (TGF)-beta 1 does not predict advanced liver fibrosis in children with chronic hepatitis B. Hepatogastroenterology. 2004;51(55):229-33.

14. Akpolat N, Yahsi S, Godekmerdan A, Demirbag K, Yalniz M. Rela- 
tionship between serum cytokine levels and histopathological changes of liver in patients with hepatitis B. World J Gastroenterol. 2005;11(21):3260-3.

15. Yu SK, Kwon OS, Jung HS, Bae KS, Kwon KA, Kim YK, et al. Influence of transforming growth factor-beta1 gene polymorphism at codon 10 on the development of cirrhosis in chronic hepatitis B virus carriers. J Korean Med Sci. 2010;25(4):564-9.

16. Mondelli MU, Varchetta S, Oliviero B. Natural killer cells in viral hepatitis: facts and controversies. EurJ Clin Invest. 2010;40(9):851-63.
17. Bertoletti A, Maini MK, Ferrari C. The host-pathogen interaction during HBV infection: immunological controversies. AntivirTher.2010;15 (Suppl 3):15-24.

18. McMahon BJ. The natural history of chronic hepatitis B virus infection. Hepatology. 2009;49(5 Suppl):S45-55.

19. Li J, Wu W, Peng G, Chen F, Bai M, Zheng M, et al. HBcAg induces interleukin-10 production, inhibiting HBcAg-specific Th17 responses in chronic hepatitis B patients. Immunol Cell Biol. 2010;88(8):834-41. 